\title{
35 INFORMATION TECHNOLOGY DIFFUSION IN ACADEMIC TEACHING: An Institutional Perspective ${ }^{1}$
}

\author{
Gali Naveh \\ Dorit Tubin \\ Nava Pliskin \\ Ben Gurion University of the Negev \\ Beer-Sheva, Israel
}

\begin{abstract}
Even though diffusion of information and communication technology (ICT) in academic teaching has been fast, the expected benefits in pedagogy and structure have yet to materialize. Rogers' diffusion theory, which focuses on adoption and rejection of innovation, can explain the proliferation of ICT usage in academia, but the lack of ICT-based pedagogical and structural changes are beyond the scope of diffusion theory. The objective of this paper is to broaden the theoretical base for explaining the state of ICT in academia via the alternative conceptual lens of institutional theory, which focuses on the relationship between the organization and its environment. With the institutional theory perspective in mind, we suggest that further pedagogical and structural changes in academic courses should not be expected as a result of ICT implementation in academic teaching.
\end{abstract}

Keywords Institutional theory, academic teaching, ICT diffusion

\footnotetext{
${ }^{1}$ This paper was inadvertently omitted from Organizational Dynamics of Technology-Based Innovation: Diversifying the Research Agenda (T. McMaster, D. Wastell, E. Ferneley, and J. I. DeGross, eds.), the proceedings of the IFIP 8.6 conference in Manchester, England, June 14-16, 2007 (Volume 235).
}

Please use the following format when citing this chapter:

Naveh, G., Tubin, D., and Pliskin, N., 2008, in IFIP International Federation for Information Processing, Volume 287, Open IT-Based Innovation: Moving Towards Cooperative IT Transfer and Knowledge Diffusion, eds. León, G., Bernardos, A., Casar, J., Kautz, K., and DeGross, J. (Boston: Springer), pp. 563-567. 


\section{BACKGROUND}

A large investment has been made in integrating information and communication technology (ICT) into academic courses (see Bennett and Bennett 2003; Collis and Moonen 2001; Harasim 2000; Macchiusi and Trinidad 2001; Mason 2000; Noble 2001; Rafaeli et al. 2003). Surveys show massive ICT usage in academic courses (Green 2002, 2003, 2004), but only sparse anecdotal evidence of fundamental instructional change is found in the literature (Chiang and Fung 2004; Ellis et al. 2005; Thompson and MacDonald 2005). In fact, massive diffusion did not bring about much change either in the pedagogic way professors teach (Burgess 2003; Frank and Barzilai 2004; OECD 2005), or in the basic ways that universities structure their study programs (GuriRosenblit 2005; OECD 2005). This situation raises the question of whether expectations that ICT implementation will bring about change in the pedagogy and structure of academic teaching will ever materialize.

According to diffusion theory (Rogers 1995), the relative advantage of ICT-based courses, compared to traditional courses, explains diffusion but does not discern between different users of the same innovation. Thus, this theory cannot explain why successful cases, in which students and professors report fundamental instructional change, remain anecdotal in nature.

In the next section, a polemical perspective of diffusion theory and its explanation for the current status of ICT in academia are presented, followed in the third section by the alternative perspective of institutional theory (Meyer and Rowan 1992; Rowan and Miskel 1999). Some conclusions are presented in the closing section of this paper.

\section{ICT ADOPTION IN ACADEMIA}

Rogers' diffusion-of-innovation theory (1995), which treats adoption of innovation dichotomously, might not be sufficient for explaining a situation where the innovation is being used without fulfilling its potential, as in the case of ICT-based academic courses. Rogers ascribes innovation success to its use but does not consider consequences of use as relevant to determining the success of the adoption process. Thus, the current status of massive ICT usage in academic courses would be considered successful according to diffusion theory, leaving the question of missing pedagogical and structural change unexplained. Part of the answer rests on the definition and measurement of success in the complex context of ICT innovation, as evident in research by DeLone and McLean (1992, 2003) and Seddon et al. (1999).

DeLone and McLean thoroughly examined the definition and measurement of success in implementing ICT and found dozens of definitions, techniques, and tools. One of the implications of their work is that ICT success in implementation may be defined and measured in more than one way. Seddon et al. emphasize that the criteria for success may differ from one stakeholder to another, even in the same situation.

The relevant stakeholders according to the diffusion-of-innovation model are the users of the innovation. The users in the academic context could be the students, professors, university officials, or different entities in the academic organizational field. Rogers' theory does not discern among stakeholders, and thus success for one entity 
could be perceived completely different by another entity. Better explanation could perhaps be obtained by institutional theory (Meyer and Rowan 1992; Rowan and Miskel 1999), which suggests that agents in the academic environment are relevant to defining ICT-based use as success.

\section{INSTITUTIONAL THEORY PERSPECTIVE}

Every organization belongs to an organizational field or sector. According to institutional theory, many organizational processes and changes, with which an organization allegedly intends to promote efficiency, are actually performed in order to achieve environmental legitimacy by meeting regulations, norms, and ideology of its organizational field (Rowan and Miskel, 1999). Thus, to enhance its survival prospects in its competitive environment, sometimes an organization seeks to increase environmental support and resources flow at the expense of organizational efficiency (Meyer and Rowan 1992; Scott 2003).

Universities are expected by their stakeholders (students, potential students, regulators, and funding agencies) to be in a leading position in the process of adopting technological innovations. Since higher education has become more competitive in recent years, the pressure to become more efficient and offer better service to student customers is increasing.

Once perceived as adopting technological innovation (ICT, in this case) as a means for improving the service provided to students, the university, as an institute acting according to institutional theory, has achieved its goal of maintaining environmental legitimacy. This may be accomplished without the need to perform meaningful, significant, resource-consuming pedagogical and structural changes in academic courses and programs. Organizational field expectations, therefore, might be met even with superficial and symbolic ICT adoption. Thus, with the institutional theory perspective in mind, one should not expect in-depth changes as a result of ICT implementation in academic teaching. Rather, the ICT adoption process could be considered successful as long as, while adopting ICT, universities are able to sustain environmental legitimacy by being perceived in their organizational field as adopters of technological innovations. Indeed, while massive adoption of ICT in academic teaching has occurred, lack of further impact on the technical core (i.e., the set of activities required in order to achieve the organizational goals) of the university may indicate that the goal of maintaining environmental legitimacy has been accomplished.

\section{CONCLUSIONS}

ICT, while used widely, has yet to meet its pedagogic and structural potential. This suggests that the mere adoption of a technological innovation may not be perceived as successful by some stakeholders and presents a more complex picture than diffusion theory. DeLone and McLean suggest that ICT success may be measured in various ways in different situations and according to different stakeholders, in line with institutional 
theory. With an institutional theory perspective in mind, the university as an institution strives to maintain environmental legitimacy by being perceived as using ICT in academic teaching, without making significant changes in its technical core. This perspective suggests that further pedagogical and structural changes resulting from ICT integration in academic courses should not be expected.

\section{References}

Bennett, J., and Bennett, L. 2003. "A Review of Factors that Influence the Diffusion of Innovation When Structuring a Faculty Training Program," The Internet and Higher Education (6), pp. 53-63.

Burgess, L. A. 2003. "WebCT as an e-Learning Tool: A Study of Technology Students' Perceptions," Journal of Technology Education (15), pp. 6-15.

Chiang, A. C., and Fung, I. P. 2004. "Redesigning Chat Forum for Critical Thinking in a Problem-Based Learning Environment," The Internet and Higher Education (7), pp. 311-328.

Collis, B., and Moonen, J. 2001. Flexible Learning in a Digital World: Experiences and Expectations, London: Kogan Page.

DeLone, W. H., and McLean, E. R. 1992. "Information Systems Success: The Quest for the Dependent Variable," Information Systems Research (3), pp. 60-95.

DeLone, W. H., and McLean, E. R. 2003. "The DeLone and McLean Model of Information System Success: A Ten-Year Update," Journal of Management Information Systems (19), pp. 9-30.

Ellis, R. A., Marcus, G., and Taylor, R. 2005. "Learning through Inquiry: Student Difficulties with Online Course-Based Materials," Journal of Computer Assisted Learning (21), pp. 239-252.

Frank, M., and Barzilai, A. 2004. "Designing Course Web Sites for Supporting Lecture-Based Courses in Higher Education-Some Pedagogical Aspects," International Journal of Instructional Technology and Distance Learning (1:12).

Green K. C. 2002. The 2002 National Survey of Information Technology in U.S. Higher Education, Encino, CA: The Campus Computing Project.

Green K. C. 2003. The 2003 National Survey of Information Technology in U.S. Higher Education, Encino, CA: The Campus Computing Project.

Green K. C. 2004. The 2004 National Survey of Information Technology in U.S. Higher Education, Encino, CA: The Campus Computing Project.

Guri-Rosenblit, S. 2005. "Eight Paradoxes in the Implementation Process of E-Learning in Higher Education," Higher Education Policy (18), pp. 5-29.

Harasim, L. 2000. "Shift Happens: Online Education as a New Paradigm in Learning," The Internet and Higher Education (3), pp. 41-61.

Macchiusi, L., and Trinidad, S. 2001. "Information and Communication Technologies: The Adoption by an Australian University," in Expanding Horizons in Teaching and Learning: Proceedings of the $10^{\text {th }}$ Annual Teaching Learning Forum, A. Herrmann and M. M. Kulski (eds.), February 7-9, Curtin University of Technology, Perth, Australia (http://cleo.murdoch. edu.au/confs/tlf/tlf2001/macchiusi.html; retrieved March 9, 2003).

Mason, R. 2000. "From Distance Education to Online Education," The Internet and Higher Education (3), pp. 63-74.

Meyer, J. W., and Rowan, B. 1992. "The Structure of Educational Organizations," in Organizational Environments: Ritual and Rationality, J. W. Meyer and W. R. Scott (eds.), Thousand Oaks, CA: Sage Publications, Inc. 
Noble, D. F. 2001. Digital Diploma Mills, New York: Monthly Review Press.

OECD. 2005. "E-Learning in Tertiary Education," Policy Brief, Organisation for Economic Cooperation and Development, December (http://www.oecd.org/dataoecd/55/25/35961132.pdf; retrieved July 14, 2006).

Rafaeli, S., Barak, M., Dan-Gur, Y., and Toch, E. 2003. "QSIA-A Web-Based Environment for Learning, Assessing and Knowledge Sharing in Communities," Computers and Education (43), pp. 273-289.

Rogers, E. M. 1995. Diffusion of Innovation ( ${ }^{\text {th }}$ ed.), New York: Free Press.

Rowan, B., and Miskel, C. G. 1999. "Institutional Theory and the Study of Educational Organizations," in Handbook of Research on Educational Administration, J. Murphy and K. S. Louis (eds.), San Francisco: Jossey-Bass Inc.

Scott, W. R. 2003. Organizations: Rational, Natural, and Open System ( $5^{\text {th }}$ ed.), Upper Saddle River, NJ: Prentice Hall.

Seddon, P. B, Staples, D. S., Patnayakuni, R., and Bowtell, M. J. 1999. "The Dimensions of Information Systems Success," Communications of the Association for Information Systems (2:20) (http://cais.isworld.org/articles/2-20/article.pdf; retrieved July 31, 2006).

Thompson, T. L., MacDonald, C. J. 2005. "Community Building, Emergent Design and Expecting the Unexpected: Creating a Quality eLearning Experience," The Internet and Higher Education (8), pp. 233-249.

\section{About the Authors}

Gali Naveh is a Ph.D. candidate in the Department of Industrial Engineering and Management, Ben-Gurion University in Israel. Gali's research is focused on organizational aspects of ICT integration in academic teaching. Gali can be reached at galin@bgu.ac.il.

Dorit Tubin, Educational Sociologist, is a faculty member in the Department of Education, Ben-Gurion University, Israel. Dr. Tubin's main interests are organizational aspects of educational innovation and higher education. Dr. Tubin can be reached at dorittu@bgu.ac.il

Nava Pliskin is in charge of the Information Systems programs at the Department of Industrial Engineering and Management, Ben-Gurion University in Israel. Previously she was a Thomas Henry Carroll Ford Foundation Visiting Associate Professor at the Harvard Business School. She acquired her Ph.D. and S.M. degrees from Harvard University. Her research, focused on longitudinal analysis of IS impacts at the global, national, organizational, and individual levels, has been published in such journals as IEEE Transactions on Engineering Management, ACM Transactions on Information Systems, The Information Society, Communications of the ACM, Decision Support Systems, Information \& Management, and Database. Professor Pliskin can be reached at pliskinn@bgu.ac.il. 